\title{
Fruit Waste Substrates to Produce Single-Cell Proteins as Alternative Human Food Supplements and Animal Feeds Using Baker's Yeast (Saccharomyces cerevisiae)
}

\author{
Asiri Nisansala Dunuweera $\mathbb{D}^{1},{ }^{1}$ Dinusha Nayomi Nikagolla, ${ }^{2}$ and Kapilan Ranganathan ${ }^{3}$ \\ ${ }^{1}$ Department of Basic Sciences, University of Peradeniya, Peradeniya 20400, Sri Lanka \\ ${ }^{2}$ Department of Biosystems Technology, Uva Wellassa University, Badulla 90000, Sri Lanka \\ ${ }^{3}$ Department of Botany, University of Jaffna, Jaffna 20400, Sri Lanka
}

Correspondence should be addressed to Asiri Nisansala Dunuweera; asirinisk@gmail.com

Received 9 March 2021; Revised 7 April 2021; Accepted 13 April 2021; Published 4 June 2021

Academic Editor: Aqeel Ahmad

Copyright (C) 2021 Asiri Nisansala Dunuweera et al. This is an open access article distributed under the Creative Commons Attribution License, which permits unrestricted use, distribution, and reproduction in any medium, provided the original work is properly cited.

\begin{abstract}
Production of single-cell proteins (SCP) utilizing food wastes is an alternative solution to meet the global protein shortage and minimize pollution problems. Utilization of fruit wastes to produce SCP via fermentation using Saccharomyces cerevisiae for animal feed and potential human food was studied. The waste materials such as Mango (Mangifera indica), Prickly Custard Apple (Annona muricata), Pineapple (Ananas comosus), Papaya (Carica papaya), Banana (Musa accuminara Colla), Mangosteen (Garcinia mangostana), Cashew apple (Anacardium occidentale), Cacao (Theobroma cacao), Jackfruit (Artocarpus heterophyllus), and Pomegranate (Punica granatum) were used as the substrates for SCP production. Maximum biomass production yield and protein production were significantly higher on the fourth day $(P \leq 0.05)$ in all the fruit waste substrates. The maximum dried biomass and the protein production were significantly higher $(P \leq 0.05)$ in the PAM substrate $(0.429 \pm 0.004 \mathrm{~g}$ and $48.32 \pm 2.84 \%$ resp.) than the others, and PGM substrate yielded significantly lower biomass and protein. Considering the moisture content and ash content, the highest values were observed in JM and BM substrates, respectively, while the least values were observed in CM and PGM substrates. The bulk density values were ranging from 0.31 to $0.61 \mathrm{~g} / \mathrm{cm}^{3}$. The values for water absorption capacity and oil absorption capacity $(\mathrm{mL} / \mathrm{g})$ were high in all substrates, and they were comparable to each of them.
\end{abstract}

\section{Introduction}

The world population is overgrowing, but the individual dietary protein requirement is not fulfilled consistently since industrialization increases without full fill human needs and requirements towards a healthy life. Protein supply poses a problem because essential amino acids cannot be replaced [1]. Although the developed countries have sorted out different ways to fulfill their protein supplementations, the developing countries are unable to build up their production capacity and economy to meet the demand for protein manufacturing. This results in the malnourishment of a vast population, especially infants and children [2]. The specific protein deficiency disorders in the people suffering from malnutrition are Kwashiorkor and Marasmus [3]. Proteins are essential biomolecules, function as structural components of cells, tissues, muscles, and organs, and are necessary to carry out the metabolic process and production of enzymes and some hormones [4].

SCP is dried cells of microorganisms used as a protein supplement in human foods or animal feeds by extracting the total amount of proteins from pure cultures or cocultures of bacteria, yeasts, fungi, and microscopic algae [5]. Most SCPs are used as an animal feed supplement, and very few are documented as food for human consumption [6]. Fats, carbohydrates, nucleic acids, vitamins, and minerals are present in SCPs [7]. Lysine and methionine are the abundant amino acids present in SCPs, which are limiting in most plant and animal-based diets [8]. There are essential requirements when producing SCPs, such as physically or 
chemically pretreated carbon source, nitrogen, phosphorus, and other nutrients. Those components are needed for the optimal growth of the selected microorganism. Also, maintenance of sterile conditions or hygienic conditions is essential to prevent contamination, pure microorganism culture, and adequate aeration must be provided due to the high aerated process [9].

Although to produce biomass of SCPs, bacteria, yeast, fungi, and algae are used widely, yeast SCP is a high-nutrient feed substitute [10]. The advantages of yeast to use as a common microorganism to produce SCPs are being easy to harvest because they are larger than bacteria, high level of malic acid content, high lysine content, the ability to grow at acidic $\mathrm{pH}$, and long history of traditional use [11]. Common substrate for SCP production is starch, molasses, fruit, and vegetable wastes.

Using plant-based substrates to produce SCPs becomes a more effective method to overcome the problem of waste management and leads to minimum cost for raw materials [12]. Further, agricultural waste as a source for SCPs could contribute to conserving the fixed carbon resources produced. The present investigation was carried out to assess the potential of various fruit wastes for cost-effective yeast biomass production. In this study, the waste materials (peels/mesocarps) of Mango (Mangifera indica), Prickly Custard Apple (Annona muricata), Pineapple (Ananas comosus), Papaya (Carica papaya), Banana (Musa sp.), Mangosteen (Garcinia mangostana), Cashew apple (Anacardium occidentale), Cacao (Theobroma cacao), Jackfruit (Artocarpus heterophyllus), and Pomegranate (Punica granatum) were introduced as a potential substrate for fermentation to produce bio protein which can be used in food as such or as animal feed.

\section{Materials and Methods}

2.1. Materials. In this study, waste materials of Mango (Mangifera indica), Prickly Custard Apple (Annona muricata), Pineapple (Ananas comosus), Papaya (Carica papaya), Banana (Musa sp.), Mangosteen (Garcinia mangostana), Cashew apple (Anacardium occidentale), Cacao (Theobroma cacao), Jackfruit (Artocarpus heterophyllus), and Pomegranate (Punica granatum) were used as a carbon source for fermentation by Baker's yeast. All the fruits and Baker's yeast (Mayuripan brand) were purchased from the supermarket in Colombo (Kiribathgoda), Sri Lanka.

2.2. Preparation of Fruit Waste Media. The fruits were washed five times with regular tap water and twice with sterile distilled water, and the remaining water was removed by sterile cotton. The peels of fruits were collected to further experiments.

They were blended separately with sterile distilled water in a $1: 1$ ratio $(\mathrm{g} / \mathrm{g})$ to obtain a pulp. Then, the blended fruit waste pulps were filtered through a muslin cloth to trap the solid residues. Then, $100 \mathrm{ml}$ of the above pulps were separately added to $250 \mathrm{~mL}$ Erlenmeyer flasks and autoclaved at $121^{\circ} \mathrm{C}$ for 15 psi and 15 minutes. Samples were prepared in triplicate.

2.3. Preparation of Baker's Yeast Culture. Baker's yeast was soaked in sterile sugar water $(1: 4 \mathrm{w} / \mathrm{w})$ overnight. Then, it was cultured on Yeast Peptone Dextrose Agar media (YPDA), which contains Yeast Extract $10 \mathrm{gL}^{-1}$, Peptone $20 \mathrm{gL}^{-1}$, Dextrose $20 \mathrm{gL}^{-1}$, Agar $15 \mathrm{~g} / \mathrm{L}$ to confirm it as a pure culture by observing the pure yeast colonies. The cultures were maintained in YPDA plates and as glycerol stocks.

2.4. Media Preparation for Fermentation. The fruit waste pulp media was prepared with the following compositions [13]. The fruit waste pulp $100 \mathrm{~mL} / \mathrm{L}$ was mixed separately with end concentration of $\mathrm{KH}_{2} \mathrm{PO}_{4} 1.0 \mathrm{~g} / \mathrm{L}, \mathrm{MgSO}_{4} .7 \mathrm{H}_{2} \mathrm{O}$

$0.5 \mathrm{~g} / \mathrm{L}, \mathrm{NaCl} 0.1 \mathrm{~g} / \mathrm{L}, \mathrm{CaCl}_{2} 0.1 \mathrm{~g} / \mathrm{L}$, and the total volume of the mixture were maintained to $1000 \mathrm{~mL}$ by adding distilled water. The $\mathrm{pH}$ of the media was maintained at 5.0 by adding $1.0 \mathrm{~N}$.

$\mathrm{H} 2 \mathrm{SO} 4$ or $1.0 \mathrm{~N} \mathrm{NaOH}$ : The mixture was autoclaved at $121^{\circ} \mathrm{C}$ for $15 \mathrm{psi}$ and 15 minutes. Then, $50 \mathrm{~mL}$ of each mixture was inoculated with baker's yeast in sterile 1X PBS $(500 \mu \mathrm{L})$, at $\mathrm{OD}_{600}=0.5$. Then, the inoculated flask was placed on a shaking incubator at $100 \mathrm{rpm}$ at room temperature. After fermentation, the mixture in the flask was poured into a centrifuged tube and centrifuged at $4000 \mathrm{rpm}$ for 20 minutes. Then, the sediment was collected and weighed before drying. After that, collected sediment was oven-dried at $50{ }^{\circ} \mathrm{C}$ for 16 hours until getting constant weight. According to the Kjeldahl method, dry weight was measured, and protein content was estimated at every two days' interval for eight days.

2.5. Moisture Content. The moisture content was calculated according to the following formula.

$$
\text { Moisture content }=\frac{(\text { Initial weight }- \text { Final weight })}{\text { Initial weight }} \times 100 \% \text {. }
$$

2.6. Ash Content. Two grams ( $2 \mathrm{~g})$ of SCP was kept in a muffle furnace at $500 \pm 5^{\circ} \mathrm{C}$ for 24 hours, and the final weight was measured after cooling the mass in a desiccator. The ash content was calculated according to the following formula.

$$
\text { Ash content }=\frac{(\text { Final weight of ash left })}{\text { Initial weight before drying }} \times 100 \% \text {. }
$$

2.7. Bulk Density. Five grams ( $5 \mathrm{~g})$ of SCP obtained from different fermentation media were separately placed in a polypropylene measuring cylinder and taped until no apparent reduction of the volume was observed. The bulk density was expressed as $\mathrm{g} \mathrm{cm}^{-3}$.

2.8. Water Absorption Capacity. Water absorption capacity (WAC) was measured according to the procedure described by [14]; ten milliliters $(10 \mathrm{~mL})$ of distilled water was added to $2 \mathrm{~g}$ of SCP from each fermentation media and allowed in a static position. After 30 minutes, each mixture was centrifuged at $2000 \mathrm{rpm}$ for $45 \mathrm{~min}$. WAC was expressed as percent water bound with each SCP. 
2.9. Oil Absorption Capacity. Two grams (2 g) of SCP was mixed with soybean oil (specific gravity: 0.902 ) and allowed in a static position for 30 minutes at room temperature. Then, each mixture was centrifuged at $2000 \mathrm{rpm}$ for $45 \mathrm{~min}$ and expressed as percent oil bound with SCP [14].

Media for each fruit were denoted as MM, PCAM, PAM, PM, BM, MSM, CAM, CM, JM, and PGM for Mango (Mangifera indica) media, Prickly Custard Apple (Annona muricata) media, Pineapple (Ananas comosus) media, Papaya (Carica papaya) media, Banana (Musa) media, Mangosteen (Garcinia mangostana) media, Cashew apple (Anacardium occidentale) media, Cacao (Theobroma cacao) media, Jackfruit (Artocarpus heterophyllus) media, and Pomegranate (Punica granatum) media, respectively.

2.10. Statistical Analysis. All the experiments were done in triplicate, and biological replicates were carried out unless otherwise indicated. The mean values and standard deviations were used to plot the graphical representations. A paired sample $t$-test was carried out for the determination of significant differences $(P \leq 0.05)$ between the mean values with IBM SPSS 23 software.

\section{Results and Discussion}

Proteins, fats, carbohydrates, ash ingredients, water, and other elements such as phosphorus and potassium are rich in SCPs [15]. Aside from the nutritional benefits of SCP, another benefit of SCP technology is constant production throughout the year. Water management strategy plays a vital role by using the waste material as the substrates [16]. A small area of land is required, and SCP is made in less time. In this study, the above fruit wastes were used according to bioavailability and affordability. These fruit wastes are one of the locally available agrowaste rich in organic matter that can be used as carbon and energy sources for microorganisms to grow to SCP production. The study investigated the viable potential of selecting peels/mesocarps of Mango (Mangifera indica), Prickly Custard Apple (Annona muricata), Pineapple (Ananas comosus), Papaya (Carica papaya), Banana (Musa), Mangosteen (Garcinia mangostana), Cashew apple (Anacardium occidentale), Cacao (Theobroma cacao), Jackfruit (Artocarpus heterophyllus) and Pomegranate (Punica granatum) as a substrate for SCP production. Through heat treatments, these wastes were converted to fermentable sugar.

Yeasts are active in an extensive temperature range with an optimum temperature of $32^{\circ} \mathrm{C}-35^{\circ} \mathrm{C}$ [17]. It is essential to maintain the $\mathrm{pH}$ when growing yeast cultures [18]. To assess the nutritional value of SCP, it is essential to consider factors such as nutrient composition, amino acid profile, and vitamin and nucleic acid content, as well as palatability, allergies, and gastrointestinal effects [19].

Batch fermentation can be considered as a closed system [20]. Initially, when the time is zero, the sterile nutrient solution in the fermenter is inoculated with microorganisms and incubated to ferment. As a result of the metabolism of the cells, the composition of the culture medium generally changes (the biomass concentration and the metabolite concentration). Under optimum physiological conditions, the inoculation of a sterile nutrient solution with microorganisms and cultivation can undergo four typical phases of growth, namely, the lag phase, log phase, stationary phase, and death phase [21]. The growth of the newly inoculated batch typically follows these mentioned phases. Initially, in the lag phase, the cell concentration does not increase very much [22]. But, when the composition of the medium and the environmental conditions in the seed culture is identical with no need for adaptation, a short lag phase occurs.

Figure 1 illustrates the dried biomass with the days' interval of each media. Considering each media overall, the dried biomass increased with the increasing four days suggesting that fermentation progressed gradually in those days. The optimum biomass was obtained on the $4^{\text {th }}$ day in all the fruit waste media, and the biomass yields were decreased gradually, suggesting nutrient depletion in the growth media. Those values are $0.383 \pm 0.002,0.342 \pm 0.004,0.429 \pm 0.004$, $0.400 \pm 0.003, \quad 0.321 \pm 0.004, \quad 0.301 \pm .002, \quad 0.391 \pm .001$, $0.360 \pm 0.003,0.370 \pm 0.002$, and $0.244 \pm .002 \mathrm{~g}$ for MM, PCAM, PAM, PM, BM, MSM, CAM, CM, JM, and PGM, respectively. Though the biomass yield was higher $(P \leq 0.05)$ in all days in PAM comparing to other media, the least biomass yield $(P \leq 0.05)$ was in PGM in all the days' intervals. This may be the high sugar content and nutrients in PAM. Over the decades, several studies have focused on exploiting pineapple waste as animal feed. However, some researchers have reported the unattractive nature of by-products from the pineapple processing industry due to its high fiber content and soluble carbohydrates with low protein content. This investigation agrees with [23] reporting that pineapple waste is the best substrate for the production of yeast biomass. The growth of fungi depends on the nutritional composition of the waste material and that can help to increase the mass [24]. Since Mango contains more nutrients, it can also be used to produce a sufficient amount of SCP [25]. Further, considering the carbohydrates and other nutrients, banana waste also contains a high amount of chemical compositions than other waste, and it supports faster growth of the fungus [26]. Although the carbohydrate composition in waste of Mangosteen and Pomegranate is not comparable to Pineapple waste, that media also contain considerable biomass in dry weight $[27,28]$. Jack fruit peels also contained a high amount of carbohydrates and protein amount, which is a good source to grow yeast or other fungi to produce SCPs [29]. Although Cashew apple is rich in minerals and vitamins, it contains a few amounts of carbohydrates and proteins, which can be used as a substrate to yeasts [30].

Measuring protein content is very important when considering the SCPs. Figure 2 illustrates the total protein percentages of each fruit waste pulp media with the days' intervals. Overall, the protein percentages increase in the first four days in each sample and then decrease gradually. This is because the nitrogen supplementation/dissolved nitrogen in the media is limited to the increasing growth rate. Further, other nutrient factors also are affected by the final production of nitrogen mass. According to Figure 2, the significantly $(P \leq 0.05)$ highest protein percentage was observed in PAM, and the significantly $(P \leq 0.05)$ lowest 


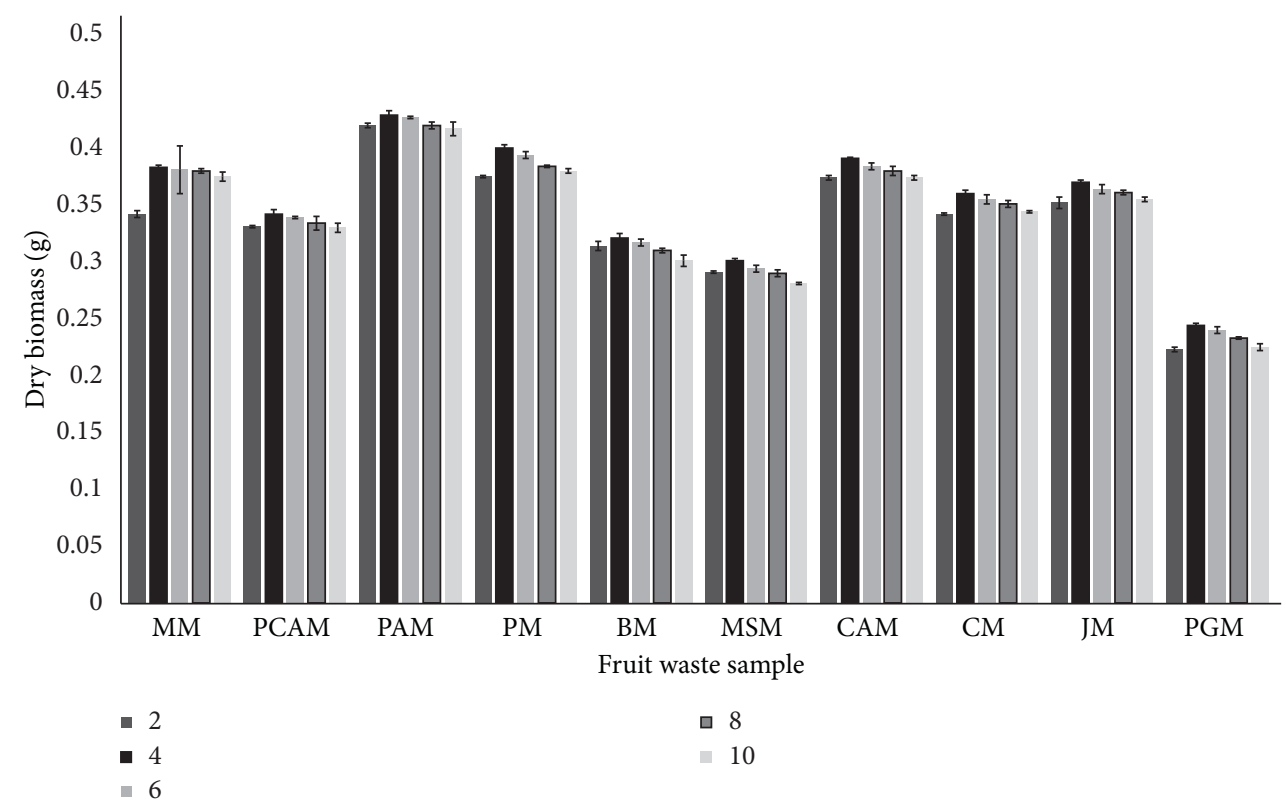

Figure 1: Dried biomass ( $\mathrm{g}$ ) of Bakers' yeast yield, produced in the various fruit wastes media in submerged fermentation at $100 \mathrm{rpm}$ on a time course basis. Each data point represents the mean \pm standard deviation $\left(n=3,{ }^{*} P \leq 0.05\right)$.

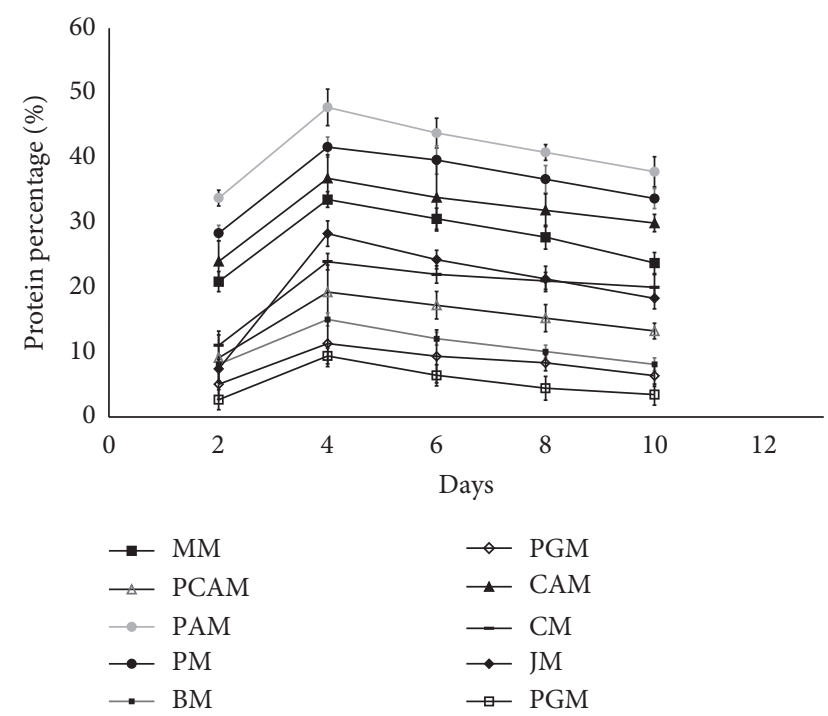

Figure 2: Protein content (\%) of Bakers' yeast biomass using various fruit wastes media in submerged fermentation at $100 \mathrm{rpm}$ on a time course basis. Each data point represents the mean\pm standard deviation $\left(n=3,{ }^{*} P \leq 0.05\right)$.

protein percentage was in PM. This is maybe due to the high nitrogen content in the PAM [31] and low content of nitrogen in the PM [32]. The protein percentages on the fourth day are $33.98 \pm 2.21,19.58 \pm 4.21,48.32 \pm 2.84,42.14 \pm 1.56$, $15.32 \pm 3.64, \quad 11.57 \pm 3.58, \quad 37.28 \pm 3.64, \quad 24.31 \pm 1.28$, $28.68 \pm 1.98$, and $9.64 \pm 1.22 \%$ for MM, PCAM, PAM, PM, BM, MSM, CAM, CM, JM, and PGM, respectively. Production of yeast protein is correlated with the nitrogen compound used in the culture medium [33]. Although protein content was calculated by multiplying total nitrogen by 6.25 , Figure 2 obtained for protein must consider other nitrogenous compounds such as purine, pyrimidine, nucleic acid, and amino sugars, in addition to true protein. Therefore, the amino acid profile of the yeast protein is more important if we consider it in amino acid levels. This suggests that amino acid content takes on considerable importance if yeasts are to be utilized as an inexpensive source of protein to supplement poor quality proteins or to serve as components of protein-rich foods.

In food processing and testing, measuring moisture content is one of the most commonly used measurements. It is due to the relation of moisture content with the alteration of food during the storage and processing and hence affects the final quality. The moisture content in percent was calculated from the weight loss, and the results are shown in Table 1. The highest moisture content was observed in the JM media significantly $(P \leq 0.05)$ while the least value was in CM significantly $(P \leq 0.05)$. The values in MM, PCAM, PAM, PM, MSM, and PGM for moisture content were significantly $(P \leq 0.05)$ different from other values, while the values of CM were different from all the other samples significantly $(P \leq 0.05)$. Overall, the values of moisture content are varying from 6 to $9 \%$. Measuring ash content refers to the inorganic residue remaining after either ignition or complete oxidation of organic matter in a food sample. The inorganic residue of the food sample refers to the total mineral present in the sample. So, the total ash content represents the proximate analysis for nutritional evaluation. The ash content of SCP was expressed as percentages of the dry weight Table 1 . The significantly $(P \leq 0.05)$ highest ash content was observed in BM, and the least value was observed in PGM, suggesting that the highest total mineral content was in BM while the least value was in PGM. The values of MM, CAM, JM, and PGM were significantly $(P \leq 0.05)$ different from all other samples, while the value of $\mathrm{BM}$ is significantly $(P \leq 0.05)$ different from all other 
TABle 1: Proximate composition and functional properties of SCP from various substrates.

\begin{tabular}{lccccc}
\hline & Moisture content (\%) & Ash content (\%) & Bulk density g/cm & Water absorption capacity mL/g & Oil absorption capacity mL/g \\
\hline MM & $7.12 \pm 0.62^{\mathrm{a}}$ & $6.23 \pm 0.66^{\mathrm{a}}$ & $0.53 \pm 0.12^{\mathrm{a}}$ & $2.14 \pm 1.01^{\mathrm{a}}$ & $1.89 \pm 0.12^{\mathrm{a}}$ \\
PCAM & $7.52 \pm 0.88^{\mathrm{a}}$ & $7.45 \pm 0.35^{\mathrm{b}}$ & $0.45 \pm 0.52^{\mathrm{a}}$ & $1.98 \pm 0.12^{\mathrm{a}}$ & $1.71 \pm 0.15^{\mathrm{a}}$ \\
PAM & $7.08 \pm 0.32^{\mathrm{a}}$ & $7.86 \pm 0.51^{\mathrm{b}}$ & $0.43 \pm 0.14^{\mathrm{a}}$ & $1.96 \pm 0.37^{\mathrm{a}}$ & $1.70 \pm 0.21^{\mathrm{a}}$ \\
PM & $6.94 \pm 0.41^{\mathrm{a}}$ & $7.51 \pm 0.42^{\mathrm{b}}$ & $0.44 \pm 0.47^{\mathrm{a}}$ & $2.02 \pm 0.52^{\mathrm{a}}$ & $1.68 \pm 0.23^{\mathrm{a}}$ \\
BM & $7.58 \pm 0.56^{\mathrm{b}}$ & $8.91 \pm 0.12^{\mathrm{c}}$ & $0.54 \pm 0.09^{\mathrm{a}}$ & $2.20 \pm 0.67^{\mathrm{a}}$ & $1.78 \pm 0.39^{\mathrm{a}}$ \\
MSM & $6.97 \pm 0.21^{\mathrm{a}}$ & $8.11 \pm 0.28^{\mathrm{b}}$ & $0.61 \pm 0.31^{\mathrm{a}}$ & $2.51 \pm 0.97^{\mathrm{a}}$ & $1.81 \pm 0.12^{\mathrm{a}}$ \\
CAM & $8.02 \pm 0.88^{\mathrm{b}}$ & $6.30 \pm 0.75^{\mathrm{a}}$ & $0.48 \pm 0.12^{\mathrm{a}}$ & $1.80 \pm 0.12^{\mathrm{a}}$ & $1.71 \pm 0.74^{\mathrm{a}}$ \\
CM & $6.34 \pm 0.45^{\mathrm{c}}$ & $5.64 \pm 0.33^{\mathrm{d}}$ & $0.31 \pm 0.19^{\mathrm{a}}$ & $1.74 \pm 0.37^{\mathrm{a}}$ & $1.59 \pm 0.39^{\mathrm{a}}$ \\
JM & $8.75 \pm 0.30^{\mathrm{d}}$ & $6.23 \pm 0.15^{\mathrm{a}}$ & $0.53 \pm 0.44^{\mathrm{a}}$ & $2.02 \pm 0.41^{\mathrm{a}}$ & $1.83 \pm 0.16^{\mathrm{a}}$ \\
PGM & $7.35 \pm 0.55^{\mathrm{a}}$ & $6.21 \pm 0.48^{\mathrm{a}}$ & $0.54 \pm 0.67^{\mathrm{a}}$ & $2.06 \pm 0.09^{\mathrm{a}}$ & $1.90 \pm 0.12^{\mathrm{a}}$ \\
\hline
\end{tabular}

samples. Functional properties of a food sample describe how ingredients behave during preparation and cooking and how they affect the finished food product in terms of how it looks, tastes, and feels. The bulk density is described as the mass of many particles of the material divided by the total volume they occupy, which includes interparticle void volume, particle volume, and internal pore volume. Considering overall bulk density values of SCP, the values were ranging from $0.310 .61 \mathrm{~g} / \mathrm{cm} 3$, and they were comparable. SCP produced in fruit waste has higher water absorption and oil absorption capacity comparatively which indicate the implementation in bakery industries; thus, it is an important functional property such as the consistency, mouthfeel and flavor stability, and enhancing and preservation.

Letters $a, b$, and $c$ were used to compare statistical significance $(P \leq 0.05)$ in the same column. Each data point represents the mean \pm standard deviation $(n=3)$.

These results can be compared with [34], which is a similar work that has been done with pineapple wastes. Further, proper aeration of the growth medium is very important in fermentation. Inadequate aeration in baker's yeasts propagation results in the production of ethyl alcohol rather than cell substance, which is reflected as a loss in cellular yield, suggesting that overaeration, however, serves no useful purpose and hence maintaining the proper growth conditions are required.

\section{Conclusions}

The above-mentioned fruit waste substrates are readily soluble in the growth medium, and the problem of contact of the yeast with the substrate is not encountered. The oxygen requirements in such systems are high due to the fact that the hydrocarbons are in a lower state of oxidation than the usual carbohydrates. These substrates are easily available, do not require separation or solvent removal, and require less agitation and cooling than hydrocarbon fermentation because these substrates release lower heat than hydrocarbons. The SCPs by yeast mainly depend on the cost of the substrate and the capital investment, including all associated costs such as collection, transportation, purification or separation, and sterilization. Since tremendous amounts of fruit wastes are available, the cost of the raw material will be low or negligible.

Since fruit waste substrates do not need purification and separation, preparation costs would be minimal compared with the use of hydrocarbons or other wastes. But if cellulose is used as a substrate, pretreatment, that is, acids, alkalis, and size reduction, is necessary to improve enzymatic hydrolysis rates. These considerations are of considerable significance in cases where the incorporation of low-technology approaches is essential.

\section{Data Availability}

All the data have been indicated in the paper either as tables or graphs (figures).

\section{Conflicts of Interest}

The authors declare that they have no conflicts of interest.

\section{References}

[1] E. Volpi, H. Kobayashi, M. Sheffield-moore, B. Mittendorfer, and R. Wolfe, "Essential amino acids are primarily responsible for the amino acid stimulation of muscle protein anabolism in healthy elderly adults," The American Journal Of Clinical Nutrition, vol. 78, no. 2, pp. 250-258, 2011.

[2] S.-H. Oh, D.-C. Ahn, and Y.-S. Kim, "A study on the mechanical properties and springback of 3D aluminum sheets," International Journal of Precision Engineering and Manufacturing, vol. 17, no. 5, pp. 671-677, 2016.

[3] K. Maleta, "Undernutrition in malawi 190 malawi medical journal special edition on burden of the disease in malawi ii," Malawi Medical Journal, vol. 18pp. 189-205, December, 2006.

[4] W. T. Ismaya, "The role of protein biochemistry in biotechnology," Inove Online, vol. 19, no. 23, pp. 11-18, 2014.

[5] A. T. Nasseri, S. Rasoul-Ami, M. H. Morowvat, and Y. Ghasemi, "Single cell protein: production and process," American Journal of Food Technology, vol. 6, no. 2, pp. 103116, 2011.

[6] S. F. S. Reihani and K. Khosravi-Darani, "Influencing factors on single-cell protein production by submerged fermentation: a review," Electronic Journal of Biotechnology, vol. 37, pp. 34-40, 2019.

[7] A. W. H. Al-Mudhafr and A. M. A. Al-Garawyi, "Microbiological sources and nutritional value of single cell protein (SCP)," International Journal for Research in Applied Sciences and Biotechnology, vol. 6, no. 6, pp. 1-3, 2019.

[8] I. sharma and K. sharma, "Banana peel extracts for the production of single cell protein by using Saccharomyces cerevisiae," International Journal of Advanced Research, vol. 5, no. 3, pp. 531-535, 2017. 
[9] M. I. Rajoka, "Production of single cell protein through fermentation of a perennial grass grown on saline lands with Cellulomonas biazotea," World Journal of Microbiology and Biotechnology, vol. 21, no. 3, 2005.

[10] A. Ritala, S. T. Häkkinen, M. Toivari, and M. G. Wiebe, "Single cell protein-state-ofthe-art, industrial landscape and patents 2001-2016," Frontiers in Microbiology, vol. 8, 2017.

[11] D. Moore, G. D. Robson, and A. P. J. Trinci, Whole Organism Biotechnology, 2013.

[12] R. Article, F. Junaid, L. A. Khawaja, and S. Ali, "Single cell protein as a potential meat substitute: a critical review," World Journal of Pharmaceutical Research, vol. 9, no. 2, pp. 141-161, 2020.

[13] R. Kapilan, S. Rajendran, and S. Vasantharuba, "Single cell protein production from papaw and banana fruit juices using baker's yeast," American-Eurasian Journal of Agricultural \& Environmental Sciences, vol. 18, no. 4, pp. 168-172, 2018.

[14] Z. U. Razzaq, M. K. I. Khan, A. A. Maan, and S. u. Rahman, "Characterization of single cell protein from Saccharomyces cerevisiae for nutritional, functional and antioxidant properties," Journal of Food Measurement and Characterization, vol. 14 , no. 5, pp. $2520-2528,2020$.

[15] S. Upadhyaya, S. Tiwari, N. Arora, and D. P. Singh, "Microbial protein: a valuable component for future food security," Microorganisms in Environmental Management, pp. 260-279, 2016.

[16] V. Bharti, P. K. Pandey, and S. K. Koushlesh, "Single cell proteins: a novel approach in aquaculture systems," Journal of the World Aquaculture Society, vol. 45, no. 4, pp. 62-63, 2014.

[17] S. H. Mohd Azhar et al., "Yeasts in sustainable bioethanol production: a review," Biochemistry and Biophysics Reports, vol. 10, pp. 52-61, 2016.

[18] N. V. Narendranath and R. Power, "Relationship between $\mathrm{pH}$ and medium dissolved solids in terms of growth and metabolism of lactobacilli and Saccharomyces cerevisiae during ethanol production," Applied and Environmental Microbiology, vol. 71, no. 5, pp. 2239-2243, 2005.

[19] M. R. Ajiboye and J. K. Odaibo, "Single cell Proteins: as nutritional enhancer," Advances in Applied Science Research, vol. 2, no. 5, pp. 396-406, 2011.

[20] T. Li, X.-B. Chen, J.-C. Chen, Q. Wu, and G.-Q. Chen, “Open and continuous fermentation: products, conditions and bioprocess economy," Biotechnology Journal, vol. 9, no. 12, pp. 1503-1511, 2014.

[21] M. D. Rolfe, C. J. Rice, S. Lucchini et al., "Lag phase is a distinct growth phase that prepares bacteria for exponential growth and involves transient metal accumulation," Journal of Bacteriology, vol. 194, no. 3, pp. 686-701, 2012.

[22] R. L. Bertranda, "Lag phase is a dynamic, organized, adaptive, and evolvable period that prepares bacteria for cell division," Journal of Bacteriology, vol. 201, no. 7, pp. 1-21, 2019.

[23] J. K. M. Mensah and P. Twumasi, "Use of pineapple waste for single cell protein (SCP) production and the effect of substrate concentration on the yield," Journal of Food Process Engineering, vol. 40, no. 3, 2017.

[24] M. I. Rashid, L. H. Mujawar, T. Shahzad, T. Almeelbi, I. M. I. Ismail, and M. Oves, "Bacteria and fungi can contribute to nutrients bioavailability and aggregate formation in degraded soils," Microbiological Research, vol. 183, pp. 26-41, 2016.

[25] K. S. Marius, N. Mahamadi, K. Ibrahim et al., "Production of single cell protein (SCP) and essentials amino acids from Candida utilis FMJ12 by solid state fermentation using mango waste supplemented with nitrogen sources," African Journal of Biotechnology, vol. 17, no. 23, pp. 716-723, 2018.

[26] S. P. Meyers and S. L. Chung, "Bioprotein from banana wastes," Abstracts of the Annual Meeting of the American Society for Microbiology, vol. 77254 pages, 1977.

[27] D. Kumar, "Analysis of physio-chemical properties of mangosteen rind Extract from industrial waste," International Journal of Trend in Scientific Research and Development, vol. 2, no. 6, pp. 1522-1526, 2018.

[28] S. C. Kushwaha, "Nutritional composition of detanninated and fresh pomegranate peel powder," IOSR Journal Of Environmental Science, Toxicology And Food Technology, vol. 7, no. 1, pp. 38-42, 2013.

[29] F. Akter and M. A. Haque, "Jackfruit waste: a promising source of food and feed," Annals of Bangladesh Agriculture, vol. 23, no. 1, pp. 2521-5477, 2019.

[30] A. Dossa, "Nutritional profile and chemical composition of juices of two cashew apple 's varieties of Benin," Chemistry (Easton).vol. 4, no. 4, pp. 91-96, 2018.

[31] E. Castillo-González, M. R. Giraldi-Díaz, L. De Medina-Salas, and M. P. SánchezCastillo, "Pre-composting and vermicomposting of pineapple (Ananas comosus) and vegetable waste," Applied Sciences, vol. 9, no. 17, 2019.

[32] S. Farazandemehr, H. Radnezhad, and M. Nourouzi, "The effects of different pomegranate wastes, poultry manure and cow sludge ratios on biogas production," International Journal of Earth and Environmental Sciences, vol. 2, no. 3, p. 129, 2016.

[33] D. Lapeña et al., "Production and characterization of yeasts grown on media composed of spruce-derived sugars and protein hydrolysates from chicken by-products," Microbial Cell Factories, vol. 19, no. 1, pp. 1-14, 2020.

[34] D. Dhanasekaran, S. Lawanya, and S. Saha, "Production of single cell protein from date waste," By-Products of Palm Trees and Their Applications, vol. 11, pp. 303-312, 2019. 